\title{
Analysis of the Real Situation of Teaching Reading Comprehension to First Year Students at the Department of English Language and Literature at Al-Zaytoonah Private University of Jordan
}

\author{
Basel Al-Sheikh Hussein \\ Assistant Professor, Department of Language and Literature \\ Al-Zaytoonah Private University of Jordan, Amman, Jordan \\ E-mail: ibrashihab@yahoo.com
}

Received: November 22, 2011

Accepted: December 19, 2011

Published: April 1, 2012

doi:10.5539/ass.v8n4p237

URL: http://dx.doi.org/10.5539/ass.v8n4p237

\begin{abstract}
There is a trend in teaching foreign languages that advocates the prime importance of teaching reading as a receptive skill before the other productive skills (listening, speaking, and writing).There is also an increasing feeling among teachers and educators that reading should receive a considerable amount of attention in teaching a foreign language.

Reading is an essential skill for students not only because it is a source of pleasure and getting information but also because it helps them widen and deepen their knowledge of language. Reading in this sense is not the mere mouthing of words and decoding of every word in every sentence. It is rather the activity that enables the students to go deeper and deeper to get the meaning which is intended by the author. It is the activity that depends largely on comprehension. Accordingly, developing reading comprehension is one of the great aims of teaching English. It is reading comprehension that enables students to pursue their studies and to meet their interests in all fields of knowledge. Thus, reading comprehension should receive more emphasis throughout the teaching process.

The importance of this study is to help students realize that they are literary readers and their attempts to go beyond the literal meaning are very limited.

Moreover, this study attempts to make students aware of the fact that reading comprehension is a process of thinking, evaluating, judging, imagining, and problem solving.

The study yields that:

1) First year students lack many important reading comprehension skills which they should have in order to understand fully a piece of writing.

2) The textbook adopted in teaching reading comprehension is mainly designed to help create readers to whom the absorbing of the literal meaning of a piece of writing is the ultimate aim of reading comprehension courses.

3) Little attention is given to teaching other important reading comprehension skills like the inferential and critical ones.
\end{abstract}

Keywords: Real situation, Teaching reading comprehension, First year students

\section{Introduction}

To master language is to master its four skills, namely listening, speaking, reading, and writing. Today, especially in designing a foreign language curriculum "... many teachers realize that the skill students need more is reading" (Dublin 1982: 14). According to Rivers (1981: 259) "reading" gives the students "the opportunity to share the thinking of the great minds of another culture and so to widen horizons of their knowledge and understanding". Thiele and Herzic (1983: 277) go beyond this. They consider reading comprehension as a dominant factor in determining whether a learner will be able to master the foreign language or not. They write: " It [reading comprehension] is a pre-requisite for the acquisition of knowledge and may play a dominant role in 
determining whether a person will ultimately succeed in mastering a foreign language or not."

\section{Significance of the study}

The importance of this study stems from its attempt to point out that good readers are engaged in the following activities:

1) They actively integrate the text to seek the meaning in the writer's mind.

2) They compare what the writer is saying with their own experience both in life and language.

3) They adjust their reading approach in accordance with the purpose for which they are reading.

4) They delay "the put-down moment" and can tolerate a high degree of incomprehension while they are searching out the meaning.

5) They adjust and revise their views in the light of what they read.

\section{Purpose of the study}

Viewing the real situation of the first year students, it can be maintained that the students lack most of the characteristics listed above. According to Al-Rufai (1977: 49) Arab readers are "Word by word readers. That is to say, they only pay their attention to pronouncing words without taking into consideration the deep meanings which the writer may want the reader to grasp."

This study aims at:

1) finding out the sources which cause the problems encountered by first year students attending reading courses.

2) suggesting a better situation to teach reading.

\section{Review of related literature}

\subsection{Reading comprehension in definition}

Giving a satisfactory definition for reading comprehension is not an easy task and still constitutes a problem. The problem stems from the fact that reading comprehension is an involved area. It involves in many fields of study, such as cognitive psychology, psycholinguistics and linguistics. It also embraces a number of mental processes. Spiro, Bruce, and Brewer (1980: XV) emphasize this fact. They write "one problem faced by anyone seeking to understand current beliefs about comprehension is the interdisciplinary nature of research in this area. There are no readily available syntheses of the relevant work in the diverse discipline of cognitive psychology, artificial intelligence, linguistics, and reading education."

To shed more light on the notion of " reading comprehension " the researcher will tend to define the two words that form the notion.

Viewing reading books and articles written by those who have the interest in reading researches, one finds many definitions for " reading". These definitions can be categorized into two main categories. First, there are definitions that talk about " reading" as if it is only the mere mouthing of words, which is true in the early stages of reading. Second, there are definitions that lay great weight upon the meaning of what is read as the ultimate goal for " reading".

Flesch (1955: 110), for instance, defines "reading" as "getting the meaning of words formed by letters on a printed page and nothing else". This definition can be classified within the first category. Harris (1970: 3), on the other hand, defines "reading" as "the meaningful interpretation of written or printed verbal symbols." Accordingly, the accuracy of "reading" depends upon the reader's perception and apprehension of the words written by the writer, and thus upon understanding of the meaning he intends to convey.

As for the definition of the second word in the term "reading comprehension", specialists also face many problems because "comprehension", as it is seen by Smith (1963: 257), "is a big blanket term that covers a whole area of thought-getting processes in reading".

For Lunzer and Dolan (1980: 257) "comprehension" is conceived of as "a measure of the pupil's ability and willingness to reflect on whatever it is he is reading." This means that the reader does two things in his reading process; one of them is certainly reading, and the other one is not only understanding but in some sense thinking.

In spite of the separate definitions of the two words which form the notion "reading comprehension", they stand in a close relationship to each other. Fairbanks (1937: 81) shows this close relationship between "comprehension" and "reading". He found that poor readers made an average of 5.8 oral errors per 100 words; on 
the contrary, good readers made only 2.1 errors per 100 words. More relevant is the fact that in 51 percent of the cases the errors of the poor readers tended to change the meaning, but the errors of the good readers never did. The good readers also corrected their own errors more often than the poor readers did. Fairbanks concludes that the basic problem of the poor readers is the lack of comprehension. Thus, effective reading is not only a process in which the reader reconstructs a message put in graphic symbols by the writer, but also one of seeking the meanings beyond the surface level of the graphic symbols.

In brief, the above opinions and views clearly show that comprehension is the ultimate objective of all reading. To make use of this fact, specialists believe that reading instruction for all levels should be a matter of developing comprehension, as Tinker and McGullough (1975: 197) point out:

"The fundamental goal in seeking to produce nature readers is to have them able to comprehend whatever printed materials will serve their purpose, no matter how difficult these materials may be. The acquisition of a sight vocabulary and of skill in recognizing words, and of verbal facility in general, all are aimed at promoting the understanding and interpretation of the meanings embodied in printed symbols."

How difficult to give a comprehensive and unified definition for the term " reading comprehension " can also be seen from considering its components (skills).

\subsection{Reading comprehension skills}

To many experts and specialists the " reading comprehension " process can be broken into a number of skills. These skills are interrelated and the acquisition of certain ones will pave the road for acquiring others. Thonis (1970: 67) writes:

"Each skill in every phase of growth in reading becomes an essential building block which adds to the learner's strengths, and make it possible for him to add new, more difficult skills"

He adds that " skills development must proceed along an orderly and sequential path so that success in simple skills at an early level may support the more difficult." (Ibid)

Listing these skills in one unified form, or giving more weight for one skill than another is not possible for reasons mentioned by Lewis and Sisk (1963: 111):

"No matter how one lists the various reading abilities [skills], it is practically impossible to isolate them or to give priority to one skill. All comprehension skills are interrelated, and the sequence of skills is therefore almost impossible to determine accurately"

The interrelated nature of the reading comprehension skills makes it difficult to see them as separate entities. No one can put a firm border between them, because the comprehension of a piece of writing is the immediate outcome of the interrelationship between these different skills. Lewis and Sisk cite an example of the interrelation of comprehension skills:

"if asked to state the first or basic comprehension skills required, many people would name the ability to grasp main ideas. But by what process does one arrive at the main idea except by putting together details? And one must understand the relationship of these details to one another. Therefore, the ability to select details is basic, as the ability to weigh the comparative importance of details." (Ibid)

To explain the difficulty of giving a unified definition for the term "reading comprehension', 'the researcher introduces below some lists of reading comprehension skills. Each list gives a number of skills which are considered essential to comprehend a piece of writing.

Hildreth (1965:455), for instance, defines "reading comprehension" as comprising the ability to:

1) follow the sequence of ideas .

2) grasp details .

3) catch the general significance and implications of statements made, and

4) to evaluate them and make inferences from them .

Carrol (1973:2) finds that only five skills are worth noting.

1) Remembering the meanings of words.

2) Following the structure of a passage. 
3) Finding answers to questions answered explicitly or in paraphrase.

4) Recognizing the writer's purpose, attitude, tone, and mood.

5) Drawing inferences from the context.

Kelly and Greene (1953: 2) consider seven skills to be indispensable to effective reading:

1) Skimming to locate passages containing answers to specific questions.

2) Careful and critical reading to identify details necessary to answer specific questions.

3) Selecting the central idea or theme of a paragraph or a passage.

4) Making generalization from a series of related statements.

5) Drawing inferences from material read.

6) Summarizing in a few words the gist of a paragraph.

7) Remembering material read in the light of a specific purpose.

According to Dechant and Smith (1977:239-240), the good comprehender should posses twenty-two skills.

Viewing the above-listed and mentioned skills, one can notice that there is no complete agreement among scholars and specialists of reading as to the exact number of skills. Moreover, the above lists of the skills show that there is no agreement on what skills good comprehenders are expected to develop, nor on the grouping of these skills into distinguished levels (Jenkins and Panny, 1980: 56) .It seems that the only principle that necessitates such grouping is of a pedagogical nature (Pumfrey, 1977: 40-42).

There is another view than breaking down the process of " reading comprehension " into skills. It believes that " comprehension is one unified whole called the reading comprehension skill. (Lunzer et al, 1979:37).

Lunzer and Dolan (1980: 77) argue that there is no research evidence which supports the idea of breaking down the comprehension process into discrete skills. They write that:

"It is too easy for the naive or uninformed to assume that comprehension is really divisible into separate skills. Research evidence does not support this notion. Many studies have failed to identify any discrete skills or sub-skills of comprehension. More often than not, they tend to show comprehension as more of unitary and invisible trait.

The researcher of this study favours the view of the multiplicity of "reading comprehension skills", because it gives him the ability to diagnose those skills that are mastered by the first year students and those which are not.

The view of the multiplicity of "reading comprehension skills" seems to gain a great support by the majority of writers on "reading comprehension".

Smith (1978: 190) is one of them. He thinks that "there is a feeling that comprehension itself can be broken down into a series of "comprehension skills".

Moreover, the view of multiplicity of "reading comprehension skills" has its pedagogical advantages, particularly in the organization of reading materials as well as in the construction of exercises written to strengthen specific skill(s). This view seems also to gain "face validity in terms of students' acceptance". (Brown and Hirst, 1983: 139).

\subsection{The levels of reading comprehension skills}

Many of those who are involved in studying the comprehension process hold the belief that comprehension skills can be classified into different levels. Burns and Roe (1976: 208), for instance, mention three of them, namely literal, interpretive, and creative.

Zintz (1980: 230) holds the same view. He states that "comprehension, or the understanding of what the author has written, takes place at different levels of complexity according to the nature of the materials and the purpose for which the reading is intended". Then he classifies the skills into the following:

1) Literal comprehension or the pre-interpretive skills.

2) Interpretive skills,

3) Evaluative skills. ( Ibid :231)

Accordingly, the efficient reader is the one who not only recognizes the meanings he gets from the written materials, but also the one who has the ability to interpret, evaluate, and reflect upon those meanings. 
According to Logan et al (1972: 372) and Spache (1961: 52), the "reading comprehension skills" can be classified into the following three levels:
1) Literal level.
2) Inferential level.
3) Critical level.

The literal level of comprehension is the direct level in which one identifies what the words say; it does not involve determining what the words beyond their literal meaning mean. It deals with facts, such as dates, names, places, and with all that can easily state and comprehend, once the meaning of unknown words is known. Sometimes, the literal level is called "receptive level, since this type of comprehension involves merely the intake of information" (Herber, 1967: 139). Nevertheless, it is an essential one because it constitutes the first step towards a complete understanding of a written message.

For Thomas and Robinson (1977: 133) four skills are essential to gain the literal meaning. These are:

1) Grasping directly stated details or facts.

2) Understanding main ideas.

3) Grasping the sequence of time, place, ideas, events ...etc.

4) Understanding and following directions.

A number of studies have shown that most of the directed questions to students inside the classroom tend to test mainly literal comprehension, yet fail to motivate them to cope with problems concerning the inferential and critical levels.

The inferential level of comprehension is commonly defined as:

"... arriving at something that was not directly communicated. What the something is depends on the explicit context. It may be a conclusion, an inference, a predication, identification of a cause." (Durkin, 1978:441)

The inferential level is the reaction of the reader to what is read; so it is, as Gans (1963: 198) says, "a highly personal process".

Tinker and McGullough (1975: 23) emphasize Gans's view by stating that the "interpretation of word meanings is often in terms of the reader's related experience". They add that "a reader will react in his own individual ways to the textual material and its wider references and implications in proportion as his background of experience is uniquely his own" (Ibid)

When the student reaches the second level in his reading process, this means that he goes deeper and deeper toward the third one, which is to the Critical, or Evaluative level of "reading comprehension". This level is identified by a variety of names, such as applied, creative, associational, and expressive. When dealing with the critical level of comprehension, the reader makes use of the skills which belong to the literal and interpretive levels. He gets the facts and information from the first level and the interpretation of these facts from the second. This view is emphasized by Herber (1970: 63) who believes that the reader "takes the product of literal, what the author has said, and the interpretive, what the author meant by what is said, and applies it in some pragmatic exercises."

Durrell (1949: 203) explains that the critical level includes such skills as:

1) judging suitability of material for particular purposes,

2) distinguishing between facts and opinions,

3) discovering evidence of bias of prejudice and other evaluation skills.

He adds that "critical reading may be concerned with the form of presentation of the ideas, the choice of vocabulary, sentence organization, paragraph structure, illustrations, or general quality of the writer." (Ibid)

Teachers and experts of "reading comprehension" believe that the critical level is essential for students, especially for those who are enrolled in reading comprehension courses, because understanding sentences and paragraphs does not necessarily mean that the students completely comprehend the reading materials.

Teaching students to be critical is not an easy job, "because of lack of classroom time or adequate regard of its importance or because the teacher is unsure of his ability to pursue it". (Gans, 1963: 198)

In spite of being difficult to be taught, the critical level should be emphasized by teachers in the classroom 
through all the academic stages.

Wiriyachitra also believes that the critical level "should be taught in the developmental reading program, from the beginning... through the upper levels...." (1982: 23)

\section{Data collection Procedure}

To achieve the purpose of the study, a questionnaire was used. The questionnaire contains twelve questions which are expected to cover most of the areas related to the present study. The questionnaire is so constructed to suit the first year students' linguistic level. (see appendix no. 1)

Since the questionnaire is constructed to investigate the real situation of teaching "reading comprehension", it tries to elicit the students' opinions about the value of the reading comprehension classes. In other words, the questionnaire consists of questions which aim at investigating the actual difficulties the students face in "reading comprehension courses". In addition, the questionnaire attempts to elicit the students' views on the activities followed by the teacher inside the classroom. There are also questions aiming at getting the students' opinions about some points related to the textbook used in teaching " reading comprehension". Finally, there is a question which aims at encouraging the students to give their suggestions for better teaching of "reading comprehension" and to mention problems they may face throughout their studying this course.

Each question has its alternatives, some questions have three alternatives, others have four or six. The number of the alternatives depends on the nature of the question itself.

\subsection{Subjects}

The total number of the students who respond to the questionnaire is 92 . But, it is worth mentioning that the total number of the students is not equal to all questions, because answers to certain questions are mainly determined by the answers awarded to the various items of the preceding questions.

\subsection{Administration}

Before handing over the questionnaire to the students, a few copies were shown to some teachers, in order to check its clarity and to include more relevant points or to exclude irrelevant ones.

However, prior to the distribution of the questionnaire the first year students were made familiar with the purpose behind it. Moreover, the researcher of this study read and discussed each question and its alternatives individually, using their mother tongue to avoid misunderstanding and to get reliable results. To get more confident answers, the students were asked not to write their names on their questionnaire copies.

\section{Interpretation of the results}

To achieve a satisfactory analysis of the questionnaire results, the researcher discusses each question separately. Question no. 1 is generated to investigate whether the students are aware of the importance of reading comprehension classes or not.

$<$ Insert Table 1 Here $>$

Table no. (1) clearly shows that the students are aware of the significance of " reading comprehension courses ". Most of the respondents (93\%) agree that reading comprehension classes are most important or as important as any other classes. Only a very small number of the students (7\%) thinks that reading comprehension classes are less important than any other ones. Accordingly, it can be inferred that the students' motivation is high when they attend reading comprehension classes.

Question no. 2 investigates the reasons behind the students' awareness of the significance of reading comprehension lessons.

$<$ Insert Table 2 Here $>$

As it can be clearly seen from table no. (2), the majority of the students think that reading comprehension classes are important because they give them the opportunity to know the meaning of words and because they familiarize them with the grammatical structures of English.

Accordingly, it seems that they think that the reading comprehension task is no more than knowing the meaning of words and the grammatical structures.

However, as it is clear from their responses, the students fail to identify the main aim of reading comprehension classes, namely to think creatively. Another group of students, more than $21 \%$ believes that reading comprehension lessons not only give them the chance to know the meaning of words and grammatical structures, but also they motivate them to think deeply about what they read. This group of students thinks that their 
acquaintance with the meaning of words and grammatical structures must be used as a means to an end (thinking deeply) and not as an end by itself.

Question no. 3 attempts to find out the elements to which the students give more attention when they read. It also attempts to see to what extent the students are concerned with the meaning beyond that of the literal one.

$<$ Insert Table 3 Here $>$

Table no. 3 indicates that the majority of the students (83.6\%) pay more attention to vocabulary, grammatical structures, and to getting the general meaning (to $\mathrm{a}, \mathrm{b}$, or $\mathrm{c}$ respectively). This means that they concentrate their attention only on the skills which belong to the literal level, and not on those of the inferential and critical one. Only $11 \%$ from the students' answers indicates that the students pay their attention to getting the deep meaning of the written passage, an activity which belongs to the inferential and critical levels.

Questions no. 4 and 5 attempt to know about the kind of questions and activities which are more emphasized inside the classroom.

$<$ Insert Table 4 Here $>$

Table no. (4) shows that the questions which aim at developing the literal comprehension skills are overemphasized. This is clearly seen by the answers a, b, and c. Only (16\%) of the responses claims that the questions which demand deep thinking are practiced in the classroom.

As for question no. 5 of the questionnaire, the table below clarifies the activities on which the teacher concentrates throughout his teaching process.

$<$ Insert Table 5 Here $>$

According to table no. 5, there are some activities practiced which have little to do with the developing of the comprehension skills. These are the activity of pronunciation and of writing. These two skills can be developed in courses mainly devoted to them, such courses are " phonetics " and " writing ".

Question no. 6 is about knowing whether the students face any problems with reading comprehension lessons or not.

$<$ Insert Table 6 Here $>$

Table no. (6) shows that the majority of the students answer a and b which testify that this group of students faces difficulties in their reading comprehension courses; whereas only a minority of the students ,c, claim that they do not face any problems.

Question no. 7 is designed to identify the areas that cause the difficulties for the students who answered a and b of question no. 6.

$<$ Insert Table 7 Here $>$

(70\%) of the respondents faces problems in "reading comprehension" because of their insufficient previous knowledge of English. Only (12.6\%) of the students' problems goes back to the textbook. This indicates that the textbook suits the students' linguistic background. Yet (9.8\%) of the respondents attributes their difficulties to the methods followed by the teacher inside the classroom ; whereas only $(8 \%)$ claims that their problems are caused by $\mathrm{a}, \mathrm{b}$, and $\mathrm{c}$.

Question no. 8 is constructed to those who answered alternative a of question no. 7. It aims at identifying those aspects of the textbook which cause their problems.

$<$ Insert Table 8 Here $>$

Table no. (8) submits that (67\%) of the respondents' attributes their problems to the difficulty of vocabularies; whereas $(22 \%)$ attributes the problems to the topics of the textbook. Only (11\%) faces difficulties caused by the grammatical structures of the passages used in the textbook.

Question no. 9 aims at knowing whether or not the textbook reflects cultural aspects of the English society or nearly similar ones to those of the Jordanians' or none of them.

Understanding the culture of a foreign nation is a fundamental element in the teaching process of its language.

In a foreign language text, we extract three levels of meanings; lexical, grammatical, and cultural meanings (cf. Fries, 1963: 104-12). The cultural meaning is the most difficult one, since it involves the values, the beliefs, and the attitudes of a speech community (Williamson, 1988: 8).

Reading is an interaction between writer and reader. Such an interaction can by no means be achieved without 
understanding the culture of the target language.

$<$ Insert Table 9 Here $>$

Table no (9) makes it clear that the majority of the students (57\%) do not believe that the textbook familiarizes them with the English culture. Other students answer alternative b. This group claims that the textbook reflects nearly similar cultural aspects to theirs. Only $(16 \%)$ of the students' responses testifies that the textbook provides them with the English cultural background.

Language and culture can not be separated. Neglecting cultural aspects "destroys the unity of language, severing it from its social context ... the one can not be learned without the other" (Abdur Rauf, 1988: 44).

Question no. 10 aims at finding out whether the students prefer topics of their own or those set by the teacher or by both of them.

$<$ Insert Table 10 Here>

Table no (10) clearly reveals that the majority of the students, c, believe that it is much better in a class of " reading comprehension " to read topics chosen by both, by the teacher and the students. This means that the cooperation between the teacher and the students is a very important aspect in reading comprehension lessons.

Question no. 11 is constructed to know whether the textbook reflects the students' interests or not.

$<$ Insert Table 11 Here>

According to table no. (11) the majority of the students' answers (a and b ) reveal that the textbook reflects their interests in reading. Ones' interest in reading material is an integral feature of the learning process, since it motivates the students to overcome their difficulties. According to Tinker and Mc Gullough (1975: 310) "interest breeds motivation ... The absense of the students' interests in certain subjects will complicate the reading task". Brown and Hirst emphasize this idea. They confirm that "a frequently crippling source of difficulty is the student's lack of interest in the subject" (1983: 141).

Question no. 12 intends to give the students the chance to comment on the problems they face in reading comprehension classes. The students are given the right to write their answers in Arabic, since their ability to express themselves in English is not well established. Their comments are summarized as follows:

1) The students are not well equipped with the techniques that enable them to overcome the difficult vocabularies they encounter in their reading. They need practice in word-attack skills to help them read.

2) The topics they read are not beneficial. There is no value in them, since the topics are not written to widen their knowledge and experience of life.

As for the suggestions, the students mean that:

1) the topics should be more vivid, chosen according to their past experience, interest, and according to their linguistic background knowledge.

2) it is better to use a textbook that consists of short stories, short dramas, essays, etc., to motivate the students to read deeply and give them pleasure in reading.

\section{Conclusion and suggestions}

\subsection{Conclusion}

The main aim of this study was (a) to point out the certain problems encountered by the first year students at the English department of Al-Zaytoonah Private University of Jordan, and (b) to find out what causes them, and to suggest a better situation to teach "reading comprehension".

As a result, the study yields the following points:

1) First year students lack many important "reading comprehension skills" which they should have in order to understand fully a piece of writing. Students, for instance, lack the ability to answer questions that demand the possession of skills involving deep thinking.

2) Little attention is given to teaching skills which belong to the inferential and critical levels. The questions and the activities carried out inside the classroom are almost geared towards teaching the skills of the literal level (see questions 4 and 5 of the questionnaire pp. 18 - 19).

3) The textbook does not provide the students with the necessary cultural background which can help them in the teaching process (see question no. 9 , pp. $23-24$ ). 
4) First year students are not aware of the nature of "reading comprehension" (see question no. 2, pp. 16 -17). They think that the reading comprehension process is a decoding one. So, their attempts to go beyond knowing the literal meaning are limited.

5) As noted above, the first year students have not developed well controlled reading comprehension skills. This may confirm that previous stages (secondary schools) of teaching reading comprehension had not offered students the chance actually needed for enhancing their reading comprehension skills.

\subsection{Suggestions}

In the light of the above findings, the following suggestions can be given:

1) It is important to identify those reading comprehension skills which first year students can work with. To identify these skills, it is advised to form a committee from those who have a long experience in teaching reading comprehension.

2) On the basis of the identified skills, a reliable and valid test for the new comers should be constructed. The aim of such a test is to diagnose the skills to which more time and efforts should be administered in the early week of the first semester.

3) It is more practical to use a textbook which is designed to teach the reading comprehension skills individually. Such a textbook will provide both the teacher and the students with paragraphs and short passages with their necessary exercises. These passages and exercises are designed to teach and to give practice only in the skill which is intended to be taught. Such a textbook can be used in the first semester. It will also help the teacher to concentrate in his teaching on those skills which the students lack. For the second semester the students should learn to use the learned skills in longer articles, in short stories, in short dramas, and in essays. Moreover, the textbook should familiarize the students with the culture of the nation of the language in question.

4) It is also advisable to construct and administer a simple questionnaire to new comers. This questionnaire should concentrate on knowing the students' interests in reading. The teacher can make use of the information he gets from such a questionnaire. He, accordingly, can provide his students with authentic materials.

5) The questions which are directed to the students in the classroom should concentrate not only on practising those skills which belong to the literal level, but also on the skills that belong to the inferential and critical levels.

6) Activities in reading comprehension courses should concentrate more on those skills that contribute to the developing of critical readers.

7) Because of the importance of the reading comprehension skills, it is to be recommended that the number of hours devoted to teach them should be increased. It is highly recommended that the study of reading comprehension should be included within the curriculum for other stages than the first one, if any good results are to be obtained.

8) It is to be advised to give the teacher who teaches reading comprehension the freedom to choose among the different textbooks.

\section{References}

Abdur Rauf, S.M. (1988). Culture and Reading Comprehension. English Reading Forum, xxvi, 44-46.

Al-Rufai, M. (1977). The Effect of Reading Comprehension on The Acquisition of Literary Appreciation and Criticism. IDELTI Journal, 9, 49.

Asher, J. (1965). The Strategy of Physical Response: "An Application to Learning Russian". International Review of Applied Linguistics, 3, 299-300. http://dx.doi.org/10.1515/iral.1965.3.4.291

Brown, P. and Hirst, S. (1983). Writing Reading Courses: The Interrelation of Theory And Practice. In Brumfit, C. J. (Ed.), Language Teaching Practice Projects for The Third World. Oxford Pergaman Press Ltd., and The British Council.

Burns, P. and Roe, D. (1976). Teaching Reading in Today's Elementary Schools. Chicago: Rand McNally.

Carroll, J. (1973). Defining Reading Comprehension. In Carroll and Roy (Ed.), Language Comprehension and Acquisition of Knowledge. Washington, D. C.:V.H. Winstons and Sons.

Dechant, E. and Smith, H. (1977). Psychology in Teaching Reading (2 ${ }^{\text {nd }}$ ed.). Englewood Cliffs: Prentice Hall. 
Deller, B. (1986). Making Comprehension Interesting. In Blatchford,R. (Ed.), The English Teacher's Handbook. London: Hutchinson and co. Publishers Ltd.

Dublin, F. (1982). What Every EFL Teacher Should Know about Reading. English Teaching Forum, XX, 3, 14 16.

Durken, D. (1978). Teaching Them to Read ( $3^{\text {rd }}$ ed.). Boston: Allyn and Bacon, Inc.

Durrell, D. (1949). Development of Comprehension and Interpretation. In Nelson, B. (Ed.), Reading in the Elementary School. Chicago: The National Society for the Study Education.

Fairbanks, G. (1937). The Relation Between Eye Movements and Voice in the Oral Reading of Good and Poor Silent readers. Psychological Monographs, 48, 78-107. http://dx.doi.org/10.1037/h0093394

Flesch, R. (1955). Why Johnny Can't Read. New York: Harper and Brother.

Fries, C. (1963). Linguistics and Reading. New York: Holt, Rinehart and Winston.

Gans, R. (1963). Common Sense in Teaching Reading. New York: The Bobs-Merrill Company, Inc.

Harris, A. (1970). How to Increase Reading Ability: A Guide to Development and Remedical Methods (5 ${ }^{\text {th }}$ ed.). New York: McKay Company, Inc.

Herber, H. (1967). Comprehension (can, can't) be Thought. In Greene, F., Frederick, E., and Palmatier, R. (Eds.), Reading: Practice and Perspective. New York: Syracause University Press.

Herber, H. (1970). Teaching Reading in Content Areas. New Jersey: Prentice Hall Inc., Englewood Cliffs.

Hidreth, G. (1965). Teaching Reading. New York: Holt, Rinehart and Winston, Inc.

Jenkins, J. and Panny, D. (1980). Teaching Reading in the Middle Grades. In Spiro, R., Bruce, B., Brewer, F., \& Hillsdale N. J. (Eds.), Theoretical Issues in Reading Comprehension. Lawrence Erlbaum Associates, Publishers.

Kelly, V. and Greene, M. (1953). Kelly-Greene Reading Test. New York: Yankers - on - Hudson World Book Company.

Kirn, E. and Hartmann, P. (1997). Interactions two: A Reading Skills Book $\left(3^{\text {rd }}\right.$ ed.). Singapore: The McGraw Hill Companies, Inc.

Lewis, J. and Sisk, J. (1963). Teaching English. New York: American Book Company.

Logan, V., Paterson, L. (1972). Creative Communication. Toronto: McGraw - Hill Ryerson Ltd.

Lunzer, E. and Dolan, T. (1980). Reading for Learning in the Secondary School. In Cashdan, A. (Ed.), Language Reading and Learning. Oxford: Basil Blackwell Publishers.

Lunzer, E., Waite, M. and Dolan, T. (1979). Comprehension and Comprehension Tests. In Lunzer, E., and Gardner, K. (Eds.), The Effective Use of Reading. London: Heineman Educational Books.

Pumfrey, P. (1977). Measuring Reading Abilities: Concepts, Sources, and Applications. London: Hodder and Stoughton.

Rivers, W. (1981). Teaching Foreign Language Skills ( $2^{\text {nd }}$ ed.). The University of Chicago Press.

Smith, F. (1978). Understanding Reading: Psycholinguistic Analysis of Reading and Learning to Read. New York: Holt, Rinehart and Winston, Inc.

Spiro, R., Bruce, B. and Brewer, F. (1980). Theoretical Issues in Reading Comprehension. Hillsdale N. J., Lawrence Erlbaum Associates, Publishers.

Thiele, A. and Herzic, G. (1983). Listening Comprehension Training in Teaching English to Beginners. System, 3.

Thomas, E. and Robinson, H. (1977). Improving Reading in Every Class (2 ${ }^{\text {nd }}$ ed.), Massachusetts: Allyn and Bacon Inc.

Thonis, E. (1970). Teaching Reading to non-speakers of English. London: Collier MacMillan.

Tinker, M. and Mc Gullough, c. (1975). Teaching Elementary Reading (4 ${ }^{\text {th }}$ ed). New Jersey: Prentice Hall Inc.

Williamson, J. (1988) Improving Reading Comprehension: Some Current Stratigies. English Teaching Forum, xxvi, 2.

Wiriyachitra,A. (1982). A Scientific Reading Program. English Teaching Forum, XX, 3.

Zintz, M. (1980). The Reading Process: The Teacher and the Learner ( $3^{\text {rd }}$ ed.). Iowa: Wm. C. Brown. 
Appendix no. 1

Questionnaire For The First Year Students At The Department Of English Language And Literature At Al-Zaytoonah Private University Of Jordan

This questionnaire is for my private research only, the information given will not be used for other purposes. Please put a tick $(\sqrt{ })$ inside the brackets next to the answer acceptable to you.

By "other lessons" is meant the lessons you take in your study of English, e.g. Poetry, Grammar, Prose, etc. You can write your answer to question no. 12 in your native language.

1- The lesson of reading comprehension is:
a- most important
b- as important as any other lessons
c- the less important

2- If your answer to item no. 1 is (a) or (b), is this because:

a- reading comprehension lessons help you to understand the meanings of vocabulary

b- reading comprehension lessons help you to understand the grammatical structures.

c- reading comprehension lessons help you to understand the foreign culture

d- reading comprehension lessons motivate you to think critically about what you have read

e- all of the above

3- When you read a topic in class, you usually pay more attention to:

a- vocabulary
b- grammatical sentences
c- understanding the foreign culture
d- getting the general meaning
e- getting the deep meaning

4- The questions used by the teacher in the classroom deal mainly with:

a- the meaning of words

b- the grammatical structures

c- the general meaning of the passage

$\mathrm{d}$ - the deep meaning of the passage

5- The activities which are done inside the classroom concentrate on:

a- pronunciation

b- writing

c- knowing the meaning of words

d- knowing the grammatical structures

e- knowing the general meaning

f- knowing the deep meaning

6- Do you face any problems with reading comprehension lessons
a- yes
b- to some extent
c- no 
7- If your answer to question no. 6 is either (a) or (b) is this because of
a- the textbook
b- methods of teaching
c- your previous knowledge of English in the secondary school

d- all of the above

8- If your answer to question no. 7 is (a) is this because of
a- vocabulary
b- grammar
c- the foreign culture
d- the topics

9- Do you think that the textbook you are studying reflects

a- English cultural backgrounds that can not be found in Jordanian everyday life

b- nearly similar cultural backgrounds that can be found in both the Jordanian and English everyday lives

c- none of them

10- Do you prefer to read in the reading comprehension lessons topics of
a- students' choice
b- the teacher's choice
c- both students' and the teacher's choice

11- Do you think that the textbook in your hand reflects your interest in reading
a- yes
b- to some extent
c- no

12- Do you have any comments or suggestions to put forward about the problems you face in reading comprehension lessons.

Table 1. students' opinions about whether or not they are aware of the importance of reading comprehension lessons (R.C.Ls)

\begin{tabular}{|c|c|c|c|c|c|}
\hline & \multicolumn{5}{|c|}{ The lesson of reading comprehension is: } \\
\hline & $\mathrm{a}$ & $\mathrm{b}$ & $\mathrm{c}$ & & \\
\hline & $\begin{array}{c}\text { Most } \\
\text { important }\end{array}$ & $\begin{array}{c}\text { As } \\
\text { important as } \\
\text { other } \\
\text { lessons }\end{array}$ & $\begin{array}{l}\text { The less } \\
\text { important }\end{array}$ & $\begin{array}{l}\text { Total of } \\
\text { answers }\end{array}$ & $\begin{array}{l}\text { Total of } \\
\text { students }\end{array}$ \\
\hline $\begin{array}{c}\text { No. of } \\
\text { respondents }\end{array}$ & 36 & 50 & 6 & 92 & 92 \\
\hline$\%$ & 39 & 54 & 7 & & \\
\hline
\end{tabular}


Table 2. students' views concerning the actual benefit they get from reading comprehension lessons

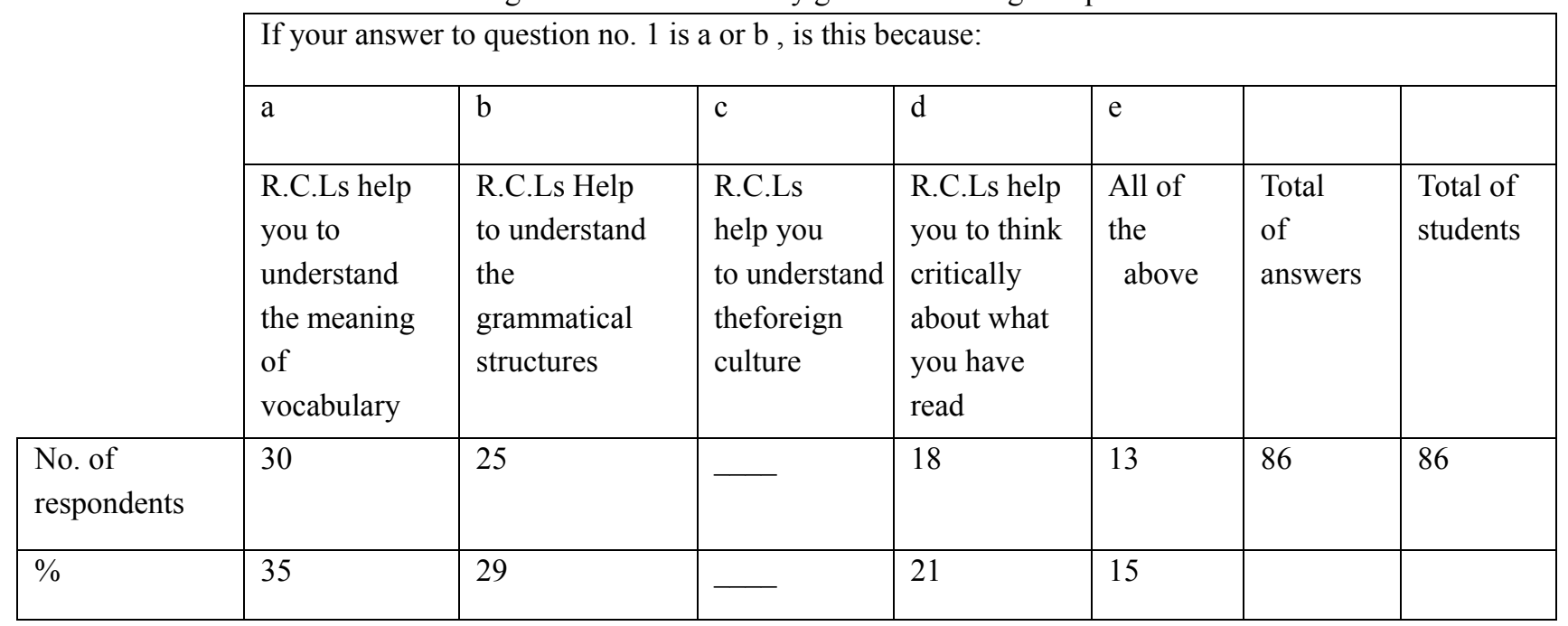

Table 3. Students' views of the elements of reading comprehension they give more attention to

\begin{tabular}{|c|c|c|c|c|c|c|c|}
\hline & \multicolumn{7}{|c|}{ When you read a topic in the classroom, do you usually pay more attention to: } \\
\hline & $\mathrm{a}$ & $\mathrm{b}$ & $\mathrm{c}$ & $\mathrm{d}$ & $\mathrm{e}$ & & \\
\hline & vocabulary & $\begin{array}{l}\text { grammatical } \\
\text { structures }\end{array}$ & $\begin{array}{l}\text { understanding } \\
\text { the foreign } \\
\text { culture }\end{array}$ & $\begin{array}{l}\text { getting } \\
\text { the } \\
\text { general } \\
\text { meaning }\end{array}$ & $\begin{array}{l}\text { getting } \\
\text { the } \\
\text { deep meaning }\end{array}$ & $\begin{array}{l}\text { total of } \\
\text { answers }\end{array}$ & $\begin{array}{l}\text { total of } \\
\text { students }\end{array}$ \\
\hline $\begin{array}{l}\text { No. of } \\
\text { respondents }\end{array}$ & 27 & 16 & 5 & 34 & 10 & 92 & 92 \\
\hline$\%$ & 29.3 & 17.3 & 5.4 & 37 & 11 & & \\
\hline
\end{tabular}

Table 4. Students' views of the questions asked by the teacher in the classroom

\begin{tabular}{|c|c|c|c|c|c|c|}
\hline & \multicolumn{6}{|c|}{ The questions used by the teacher in the classroom deal mainly with: } \\
\hline & a & $\mathrm{b}$ & $\mathrm{c}$ & $\mathrm{d}$ & & \\
\hline & $\begin{array}{l}\text { the meaning } \\
\text { of words }\end{array}$ & $\begin{array}{l}\text { grammatical } \\
\text { structures }\end{array}$ & $\begin{array}{l}\text { the } \\
\text { general } \\
\text { meaning }\end{array}$ & $\begin{array}{l}\text { the deep } \\
\text { meaning }\end{array}$ & $\begin{array}{l}\text { total } \\
\text { of } \\
\text { answers }\end{array}$ & $\begin{array}{l}\text { total of } \\
\text { students }\end{array}$ \\
\hline $\begin{array}{l}\text { No. of } \\
\text { respondents }\end{array}$ & 25 & 10 & 42 & 15 & 92 & 92 \\
\hline$\%$ & 27 & 11 & 46 & 16 & & \\
\hline
\end{tabular}

Table 5. Students' views of the activities used inside the classroom

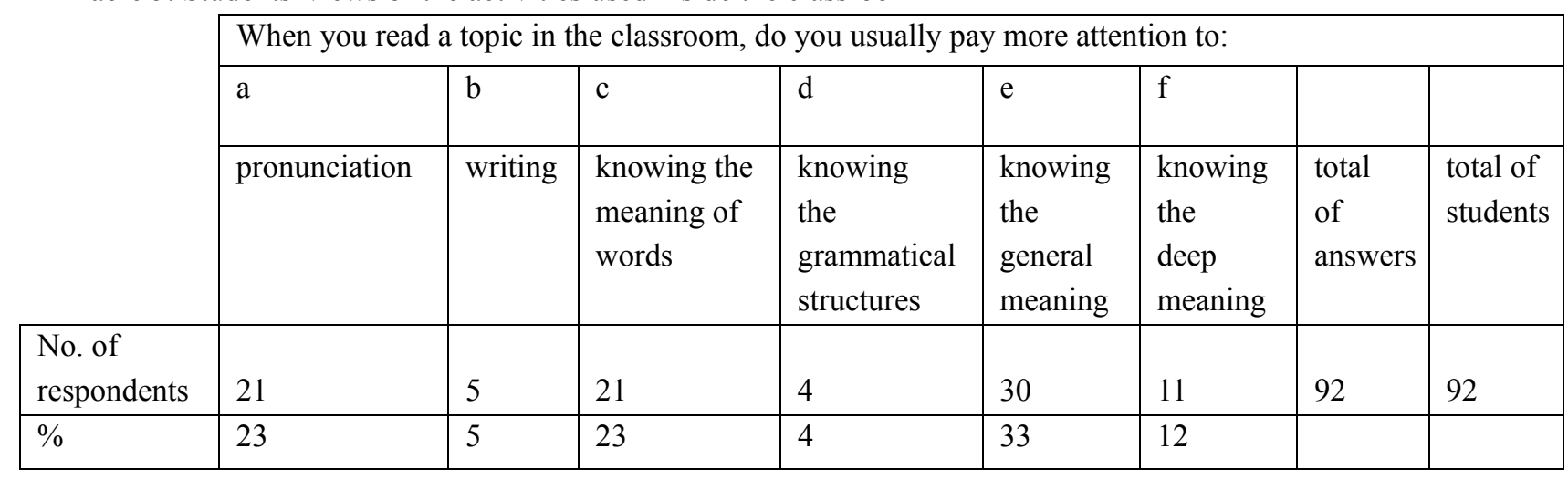


Table 6. Students' opinions about whether they face problems in reading comprehension lessons or not

\begin{tabular}{|l|l|l|l|l|l|}
\cline { 2 - 6 } \multicolumn{1}{c|}{} & \multicolumn{1}{c|}{ Do you face any problems with reading comprehension lessons: } \\
\cline { 2 - 6 } \multicolumn{1}{c|}{} & a & \multicolumn{1}{c|}{ b } & \multicolumn{1}{c|}{ c } & & \\
\cline { 2 - 6 } & yes & $\begin{array}{l}\text { to some } \\
\text { extent }\end{array}$ & no & $\begin{array}{l}\text { total of } \\
\text { answers }\end{array}$ & $\begin{array}{l}\text { total of } \\
\text { students }\end{array}$ \\
\hline $\begin{array}{l}\text { No. of } \\
\text { respondents }\end{array}$ & 19 & 52 & 21 & 92 & 92 \\
\hline$\%$ & 20.6 & 56.5 & 22.8 & & \\
\hline
\end{tabular}

Table 7. Students' opinions about the source of the problems they face in reading comprehension lessons

\begin{tabular}{|c|c|c|c|c|c|c|}
\hline & \multicolumn{6}{|c|}{ If your answer to question no. 6 is either $a$ or $b$ is this because of } \\
\hline & $\mathrm{a}$ & $\mathrm{b}$ & $\mathrm{c}$ & $\mathrm{d}$ & & \\
\hline & $\begin{array}{l}\text { the } \\
\text { textbook }\end{array}$ & $\begin{array}{l}\text { the methods of } \\
\text { teaching }\end{array}$ & $\begin{array}{l}\text { your } \\
\text { previous } \\
\text { knowledge } \\
\text { of the } \\
\text { English } \\
\text { language } \\
\text { in the } \\
\text { secondary } \\
\text { school }\end{array}$ & $\begin{array}{l}\text { all of } \\
\text { the } \\
\text { above }\end{array}$ & $\begin{array}{l}\text { total } \\
\text { of } \\
\text { answers }\end{array}$ & $\begin{array}{l}\text { total of } \\
\text { students }\end{array}$ \\
\hline $\begin{array}{l}\text { No. of } \\
\text { respondents }\end{array}$ & 9 & 7 & 50 & 6 & 71 & 71 \\
\hline$\%$ & 12.6 & 9.8 & 70 & 8 & & \\
\hline
\end{tabular}

Table 8. Students' opinions about the aspects of the textbook that cause problems to them

\begin{tabular}{|l|l|l|l|l|l|l|}
\cline { 2 - 7 } & \multicolumn{3}{l}{ If your answer to question no. 7 is either a or b is this because } \\
\cline { 2 - 8 } & a & b & c & d & \multicolumn{2}{l|}{} \\
\cline { 2 - 7 } & vocabulary & grammar & $\begin{array}{l}\text { the } \\
\text { foreign } \\
\text { culture }\end{array}$ & $\begin{array}{l}\text { the } \\
\text { topics } \\
\text { of } \\
\text { answers }\end{array}$ & $\begin{array}{l}\text { total of } \\
\text { students }\end{array}$ \\
\hline $\begin{array}{l}\text { No. of } \\
\text { respondents }\end{array}$ & 6 & 1 & - & 2 & 9 & 9 \\
\hline$\%$ & 67 & 11 & - & 22 & & \\
\hline
\end{tabular}


Table 9. Students' views of the culture the textbook reflects

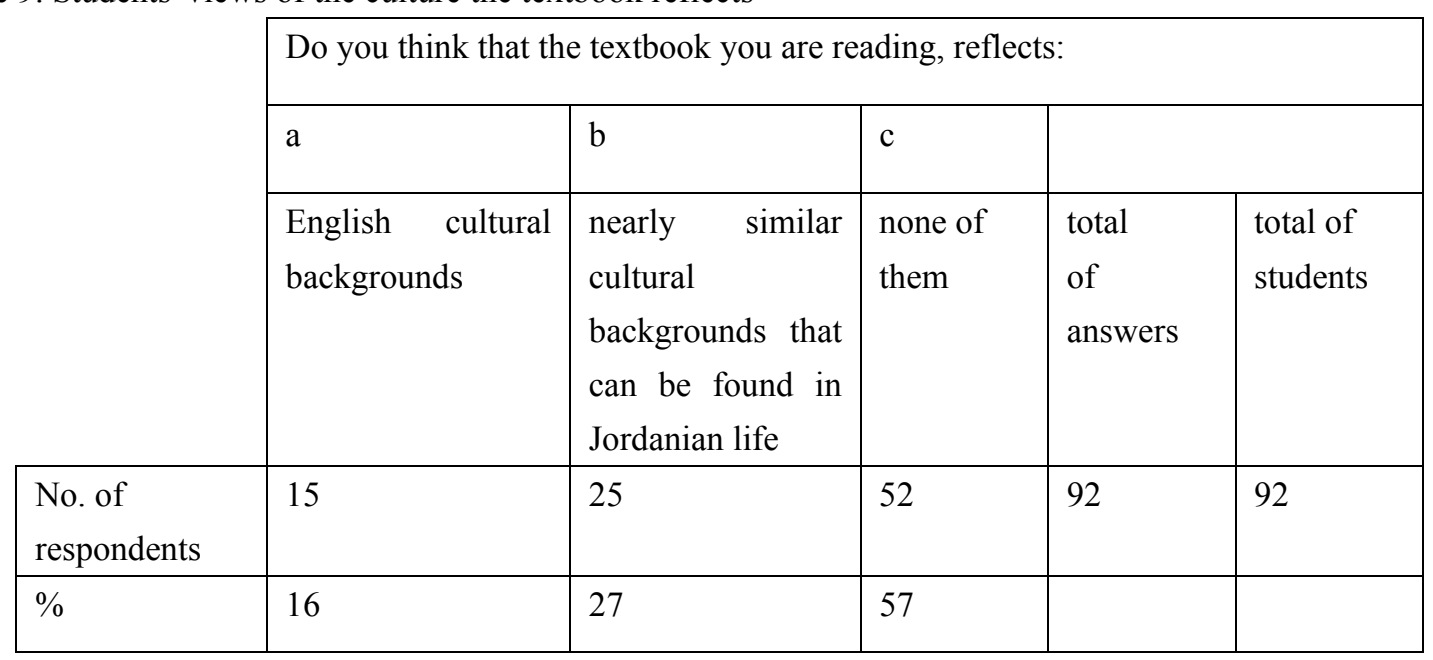

Table 10. Students' views of the choice of topics in the textbook

\begin{tabular}{|l|l|l|l|l|l|}
\cline { 2 - 6 } \multicolumn{1}{c|}{} & \multicolumn{4}{|l|}{ Do you prefer to read in the reading comprehension lessons topics of: } \\
\cline { 2 - 6 } & a & b & c & \multicolumn{2}{l|}{} \\
\cline { 2 - 6 } & $\begin{array}{l}\text { students' } \\
\text { choice }\end{array}$ & teachers' choice & $\begin{array}{l}\text { both of } \\
\text { them }\end{array}$ & $\begin{array}{l}\text { total } \\
\text { of } \\
\text { answers }\end{array}$ & $\begin{array}{l}\text { total of } \\
\text { students }\end{array}$ \\
\hline $\begin{array}{l}\text { No. of } \\
\text { respondents }\end{array}$ & 7 & 22 & 63 & 92 & 92 \\
\hline$\%$ & 8 & 24 & 68 & & \\
\hline
\end{tabular}

Table 11. Students' opinions about whether the textbook reflects their interests or not

\begin{tabular}{|l|l|l|l|l|l|}
\cline { 2 - 6 } \multicolumn{2}{|l}{} & \multicolumn{4}{|l|}{ Do you think that the textbook in your hand reflects your interests: } \\
\cline { 2 - 6 } & a & b & c & \multicolumn{2}{l|}{} \\
\cline { 2 - 6 } & yes & to some extent & no & $\begin{array}{l}\text { total } \\
\text { of } \\
\text { answers }\end{array}$ & $\begin{array}{l}\text { total of } \\
\text { students }\end{array}$ \\
\hline $\begin{array}{l}\text { No. of } \\
\text { respondents }\end{array}$ & 25 & 32 & 53 & 92 & 92 \\
\hline$\%$ & 27 & 35 & 38 & & \\
\hline
\end{tabular}

